\title{
Approaching Knowledge, Attitudes, and Practices Model for Elderly with Dementia Who are Suspected to Have Hearing Impairment in Korea
}

\author{
Sunghwa You ${ }^{1,2}$ and Woojae Han ${ }^{1,2,3}$ \\ ${ }^{1}$ Laboratory of Hearing and Technology, ${ }^{2}$ Division of Speech Pathology and Audiology, ${ }^{3}$ Research Institute of Audiology and \\ Speech Pathology, College of Natural Sciences, Hallym University, Chuncheon, Korea
}

Received March 17, 2019

Revised April 6, 2019

Accepted April 16, 2019

\section{Address for correspondence Woojae $\mathrm{Han}, \mathrm{PhD}$ \\ Division of Speech Pathology and Audiology, College of Natural \\ Sciences, Hallym University, \\ 1 Hallymdaehak-gil, \\ Chuncheon 24252, Korea \\ Tel $+82-33-248-2216$ \\ Fax +82-33-256-3420 \\ E-mail woojaehan@hallym.ac.kr}

Because the psychophysical symptoms of hearing loss and dementia in the elderly are very similar, untrained healthcare professionals in dementia facilities can easily overlook a severity of hearing loss in their patients. The present study identifies their knowledge, attitudes, and practices (KAP) on hearing loss using a survey whether they may help hearing problem of the patients with dementia. A total of 29 health-care professionals responded to the KAP survey. Also, 2 family members participated. The results showed that most of the nurses and caregivers in elderly medical welfare facilities who worked with dementia patients did not have knowledge of their hearing loss. Even the facility managers did not know how to conduct hearing tests for their patients although they did recognize that some of their patients had a hearing loss. Eventually, actual practice was not possible at this moment by the professionals. However, our respondents did have a positive attitude toward screening for hearing loss and help their patients with dementia wear hearing aids if a clinical guideline was provided. We suggest to develop clear and precise clinical guidelines of the hearing screening test for the dementia patients due to the interrelationship between dementia and hearing loss. When these guidelines apply to elderly residents in a medical welfare facility, early diagnosis and treatment of their sensory loss will help alleviate their dementia as well.

J Audiol Otol 2020;24(1):40-47

KEY WORDS: Dementia $\cdot$ Hearing loss $\cdot$ KAP survey $\cdot$ Healthcare professional · Elderly medical welfare facility.

\section{Introduction}

Since improved surgical procedures and treatment techniques have made it possible to overcome various maladies, the human life span has been extended; thus, the number of older adults is increasing globally. South Korea is also showing the same unprecedented rapid aging trend. According to the report by Korean Statistical Information Service, its ratio of elderly population will reach $20 \%$ of total population in 2025, making Korea a super-aged society [1]. Thus, common chronic diseases of the elderly are currently considered carefully at the government level, along with a need for better care

This is an Open Access article distributed under the terms of the Creative Commons Attribution Non-Commercial License (https://creativecommons.org/licenses/by-nc/4.0/) which permits unrestricted non-commercial use, distribution, and reproduction in any medium, provided the original work is properly cited. of the elderly

The elderly with dementia is globally estimated at 35.6 million as of 2012 and forecast to triple by 2050 [2]. Given that new attention, there is strong evidence that the degraded functioning of aging sensory systems may be associated with cognitive decline in the elderly. Contemporary researchers have thus investigated the relationship between hearing and/ or vision impairments of old adults and cognitive dysfunction. As examples, we summarize here eight well-designed studies [3-10] in Table 1. Although the methodology applying for functional and dysfunctional measurements of the sensory and cognitive systems were slightly different across these studies [3-5,9], all concluded that either hearing or vision loss in the older population could fatally affect any dementia. In particular, the symptoms caused by untreated hearing loss showed very similar tendencies for worsening cognitive decline or 


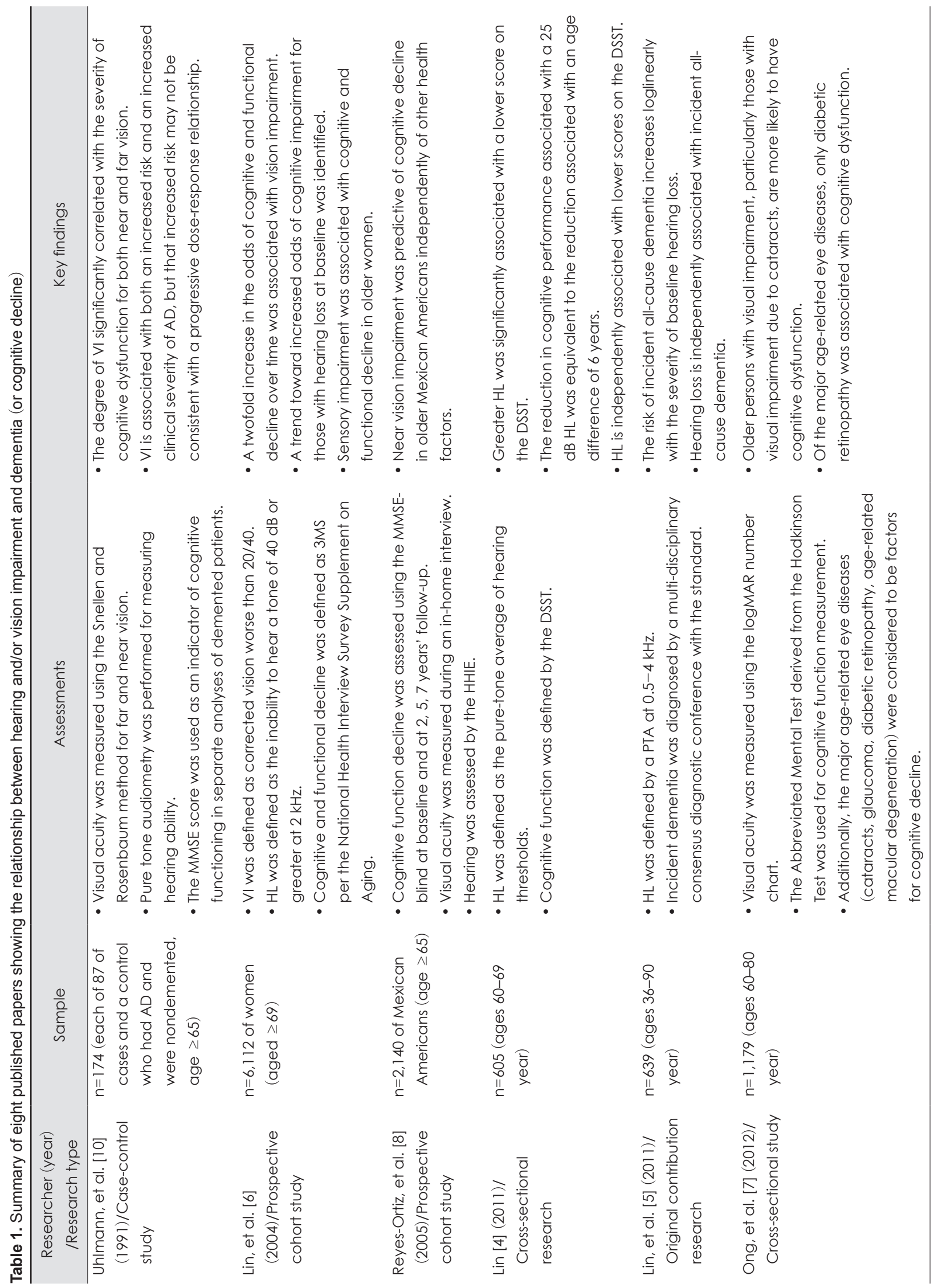




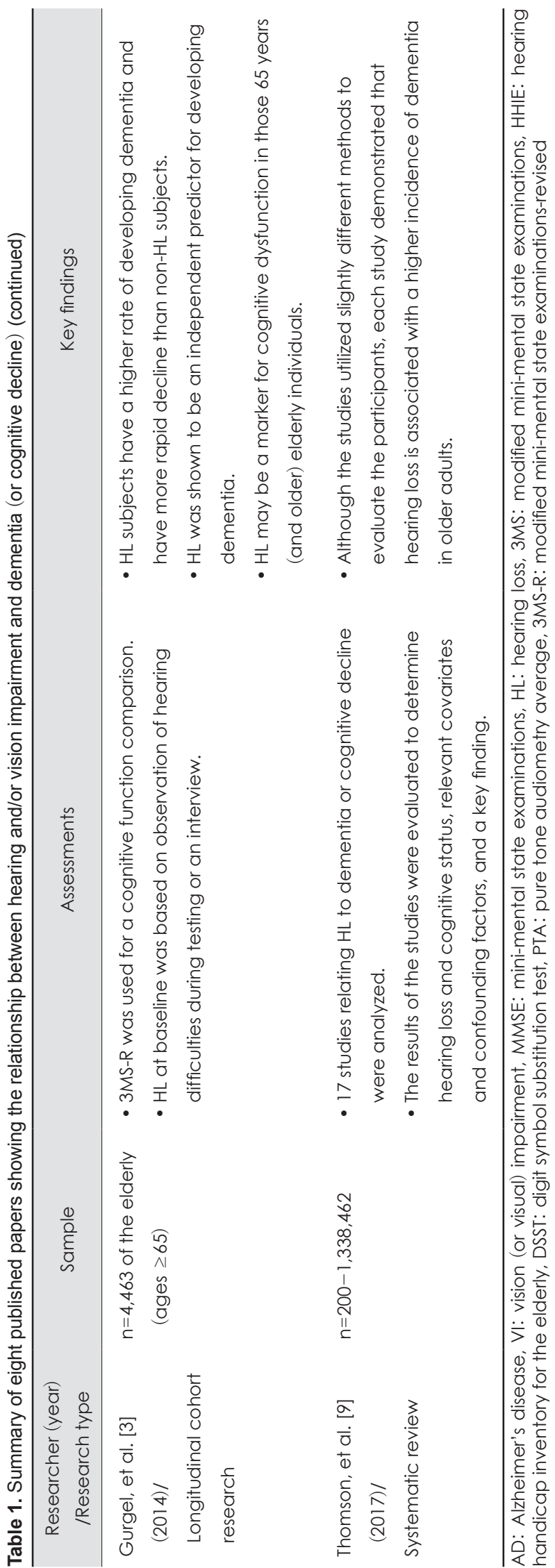

dementia, while limiting social activity and producing isolation, depression, a lower quality of life, and reduced mental well-being overall $[11,12]$.

Although each case of hearing loss and cognitive impairment can have a different characteristic due to the different sites of the lesion, i.e., the ear and brain, respectively, Fig. 1 demonstrates that the two diseases share many common psychophysical symptoms, including a lower quality of life, communication disability, social isolation, depression, and more. In other words, any patient who suffers from both dementia and hearing loss, the symptoms of hearing loss may be confusable or covered up as part of the cognitive impairment, thereby resulting in their hearing system remaining untreated. When considering the increased risks for dementia and the significant negative impact of comorbidity of two diseases on the mental well-being of the elderly, it becomes even more necessary to clinically evaluate the hearing loss in dementia patients.

On the other hand, the Knowledge, Attitudes, and Practices (KAP) survey is a representative tool used for a specific population to collect information on what is known, believed,

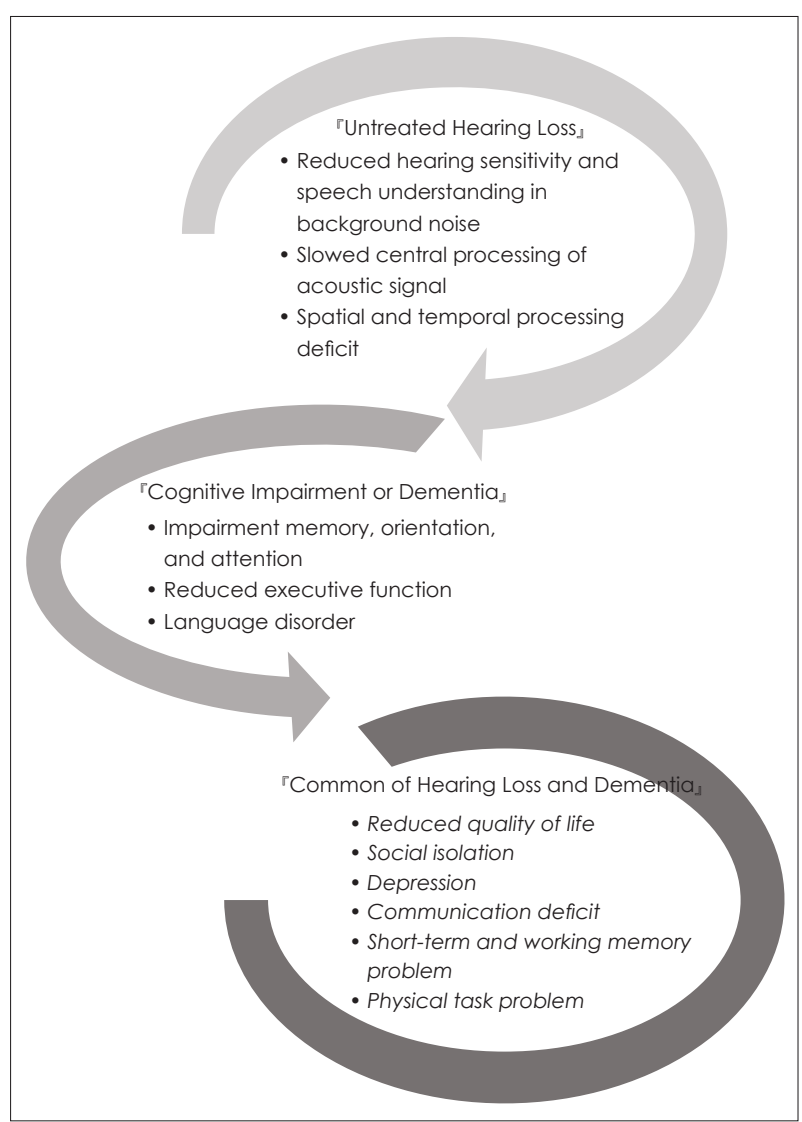

Fig. 1. Clinical and subclinical symptoms for older adults who suffer from untreated hearing impairement (top) and dementia (middle). Their common features resulting from less care by the health care professionals in their facility (bottom). 
and done in relation to a specific field. Historically, the KAP model was developed for family planning and population studies in the 1950s, with its purpose being to measure the extent to which any clear opposition to the notion and organization of family planning existed among different populations, so specific family planning practices could be used for different program purposes worldwide. In the 1960s and 1970s, the number of studies on community perspectives and human behavior grew rapidly in response to the needs of the primary health care approach that was adopted by international aid organizations [13]. Since that time, these KAP surveys had been used to investigate health behavior and continued to be widely used to gain information on health-seeking practices. Based on the KAP model, knowledge affects attitude and practice directly, and attitude will also directly affect actual practice or intentions [14]. In other words, three factors were related and thus considered together.

This brief communication identifies KAP on hearing loss of the health-care professionals in the elderly medical welfare facilities, while using a questionnaire based on that KAP model. Also, as an early stage of approach, we discuss what can be provide for them and their patients by hearing professionals in Korea

\section{Subjects and Methods}

\section{Survey items}

To develop the Korean version of KAP (K-KAP) survey, a questionnaire was adapted [15] with both translation and back-translation from English to Korean by a professional translator, and inappropriate questions related to the Korean health system were modified (i.e., the residential aged care setting in the original version of the KAP survey was modified to be an elderly medical welfare facility and long-term hospitalized facility). The final version of the questionnaire was consulted on and confirmed by professors with long careers in the Audiology and Nursing fields.

The K-KAP survey consisted of four target populations for each version: 1) Facility Manager (46 questions), 2) Nurses and Allied Health Professionals (25 questions), 3) Caregivers (25 questions), and 4) Family Members of Patients (19 questions). The version for facility workers (1 to 3 ) investigated three aspects of knowledge, attitudes, and practices- related sensory impairments for dementia, while the version of family members included several questions about sensory loss of their patients at the facility. Each version of the questionnaire had the same purpose, but it was slightly different in terms of its scope of gathered information. For example, the version for the facility manager included questions on whether employ- ees were educated for related sensory impairment for patients with dementia, how to reflect support of the management plan, and more. The version for the nurses and allied health professionals and caregivers included questions on whether they had received education about sensory loss and the interpretation of results of screening tests. In other words, the questionnaire was systematically structured in terms of each participant's position and related circumstances.

\section{Participants}

Before extending in a larger scale study in Korea, participants were randomly contacted to two facilities, one for Namyangju city and the other for Chuncheon city in easy accessibility and short duration of the pilot study. The target participants consisted of four groups' working at legally designated 'elderly medical welfare facilities' and a 'long-term hospitalized facility (in Korea, the elderly medical welfare facility provides nursing and assisting other daily life for the elderly, whereas the long-term hospitalized facility has a similar service except for professional medical services to patients by doctors and nurses)' in Korea and these facility patients' family member.

For the sample data, a total of 31 subjects completed a questionnaire with a sufficient explanation of its purpose and method. The respondents consisted of 4 facility managers, 5 nurses and allied health professionals, 20 caregivers, and 2 family members of patients. Detailed information on the respondents is included in Table 2.

All procedures for the present study were approved by Hallym University's Institutional Review Broad (HIRB-2018065) and the participants were asked to sign an informed consent before they completed the questionnaire.

\section{Results}

\section{Facility managers}

Five facility managers who have worked for nearly two years responded and recognized that a number of the dementia patients with sensory loss and the degree of their loss (4 out of 5). However, none responded and indicated they know how to screen for difficulty of hearing or vision for their patients. In terms of attitude, three out of five managers were able to test the hearing or vision when provided with specific clinical guidelines (or a program manual) and screen their patients' sensory systems. Although most of the managers did not know the guidelines well, they were positive about monitoring the hearing or vision conditions of their patients and recognized it was as necessity. Nevertheless, current situation indicated that there was no facility or staff training on doing hearing and/or vision tests as a typical practice. 
Table 2. Demographic information on study subjects $(n=31)$

\begin{tabular}{|c|c|c|c|c|c|}
\hline Questions & Response & $\begin{array}{l}\text { Facility } \\
\text { manager }\end{array}$ & $\begin{array}{c}\text { Nurse and allied } \\
\text { health care } \\
\text { professionals }\end{array}$ & Caregiver & $\begin{array}{l}\text { Family } \\
\text { members }\end{array}$ \\
\hline \multirow[t]{3}{*}{ Gender } & Male & 1 & 0 & $4(20)$ & 0 \\
\hline & Female & $4(100)$ & $4(100)$ & $16(80)$ & $2(100)$ \\
\hline & Total & 5 & 4 & 20 & 2 \\
\hline \multirow{3}{*}{$\begin{array}{l}\text { Ethnic or cultural } \\
\text { background }\end{array}$} & Korean & $5(100)$ & $4(100)$ & $20(100)$ & $2(100)$ \\
\hline & Others & 0 & 0 & 0 & 0 \\
\hline & Total & 0 & 4 & 20 & 2 \\
\hline \multirow[t]{7}{*}{ Job title } & Facility manager or deputy service manager & $1(20)$ & 0 & 0 & \\
\hline & Nurse & 0 & 0 & 0 & \\
\hline & Practical nurse & 0 & $3(75)$ & 0 & \\
\hline & Caregiver (care assistant, caregiver, etc.) & $1(20)$ & 0 & $20(100)$ & \\
\hline & Allied health professional & 0 & $1(25)$ & 0 & \\
\hline & Others & $3(60)$ & 0 & 0 & \\
\hline & Total & 5 & 4 & 20 & \\
\hline \multirow[t]{5}{*}{ Years in profession } & 2 years or less & $3(60)$ & $3(75)$ & $10(50)$ & \\
\hline & $2-5$ years & $1(20)$ & $1(25)$ & $4(20)$ & \\
\hline & $5-10$ years & $1(20)$ & 0 & $6(30)$ & \\
\hline & 10 years or more & 0 & 0 & 0 & \\
\hline & Total & 5 & 4 & 20 & \\
\hline \multirow{9}{*}{$\begin{array}{l}\text { Professional } \\
\text { qualifications }\end{array}$} & Graduate school graduation & 0 & 0 & 0 & \\
\hline & University graduation & $3(60)$ & $1(25)$ & $1(5)$ & \\
\hline & College graduation (or equivalent) & $1(20)$ & $1(25)$ & $2(10)$ & \\
\hline & High school graduation & $1(20)$ & $2(50)$ & $13(65)$ & \\
\hline & Middle school graduation & 0 & 0 & $3(15)$ & \\
\hline & No academic background & 0 & 0 & 0 & \\
\hline & Other qualifications & 0 & 0 & 0 & \\
\hline & No response & 0 & - & $1(5)$ & \\
\hline & Total & 5 & 4 & 20 & \\
\hline
\end{tabular}

Values are presented as $n$ (\%).

\section{Nursing and allied health staff}

Table 3 displays the responses from 4 nurse and allied health care professionals and 20 caregivers on their knowledge. Although 3 out of 4 nurses partially knew their patients had hearing or vision loss and the way to use to refer them to professionals, they could not conduct simple testing (100\%) and also not interpret the results $(75 \%)$ due to a lack of training and/or knowledge. Thus, they also reported having less confidence in handling assistive devices for hearing and vision. Compared to the responses of the nurses, the answers of caregivers were less knowledgeable and seemed negative.

Regarding attitudes on the KAP survey (Table 4), the respondents partially agreed with conducting screen tests for hearing or vision. In particular, the caregivers wanted more guidance about the clinical guidelines. Also $80 \%$ of the caregivers reported that their patients with dementia might actually use hearing aids effectively. In Table 5, our respondents report that most did not test or check the assistive devices of hearing and vision, such as hearing aids and spectacles, while also having no opportunity to be educated or training. There was no specialized staff to care the hearing or vision loss for their patients.

\section{Family members}

Although there was a very small sample size, family members also reported that they knew their mothers had a hearing loss, but they did not try to ask for hearing screening or care or hearing aids for her because the staffs at the facility were untrained.

\section{Conclusions and Further Implication}

The present study surveyed KAP of staffs in the aged care facility and of family members of residents towards hearing and identified any feasibility of K-KAP survey to find any relation of three factors. The current pilot data showed that 
most respondents who were nurses and caregivers in the elderly medical welfare facility and had worked for dementia patients did not have any/enough knowledge of the hearing loss of the elderly. Even the facility managers did not know about how to conduct hearing tests for their patients although they did realize that some of their patients had hearing loss.

Table 3. Sample results for knowledge section gathered from nurse and allied health care professionals $(n=4)$ and caregiver $(n=20)$

\begin{tabular}{|c|c|c|c|}
\hline Item number & Response & $\begin{array}{l}\text { Nurse and allied health } \\
\text { care professional }\end{array}$ & Caregiver \\
\hline \multirow{6}{*}{$\begin{array}{l}\text { Q1. I know which residents with dementia } \\
\text { have a hearing impairment, and use a } \\
\text { hearing aid or other aids. }\end{array}$} & Strongly agree & 0 & $3(15)$ \\
\hline & Agree & $1(25)$ & $6(30)$ \\
\hline & Neutral & $3(75)$ & $7(35)$ \\
\hline & Disagree & 0 & $4(20)$ \\
\hline & Strongly disagree & 0 & 0 \\
\hline & Total & 4 & 20 \\
\hline \multirow{6}{*}{$\begin{array}{l}\text { Q3. I am aware of brief hearing/vision tests } \\
\text { that could be used for residents with } \\
\text { dementia. }\end{array}$} & Strongly agree & 0 & $2(10)$ \\
\hline & Agree & 0 & $3(15)$ \\
\hline & Neutral & 0 & $5(25)$ \\
\hline & Disagree & $4(100)$ & $10(50)$ \\
\hline & Strongly disagree & 0 & 0 \\
\hline & Total & 4 & 20 \\
\hline \multirow{6}{*}{$\begin{array}{l}\text { Q4. I have the training and expertise to } \\
\text { administer a brief hearing/vision test and } \\
\text { interpret the results. }\end{array}$} & Strongly agree & 0 & $2(10)$ \\
\hline & Agree & 0 & $1(5)$ \\
\hline & Neutral & 0 & $5(25)$ \\
\hline & Disagree & $3(75)$ & $8(40)$ \\
\hline & Strongly disagree & $1(25)$ & $4(20)$ \\
\hline & Total & 4 & 20 \\
\hline \multirow{6}{*}{$\begin{array}{l}\text { Q5. I am aware of, and would be able to } \\
\text { use, appropriate referral pathways for any } \\
\text { patients who failed a brief hearing/vision } \\
\text { screen. }\end{array}$} & Strongly agree & 0 & 0 \\
\hline & Agree & 0 & $4(20)$ \\
\hline & Neutral & $3(75)$ & $7(35)$ \\
\hline & Disagree & 0 & $8(40)$ \\
\hline & Strongly disagree & $1(25)$ & $1(5)$ \\
\hline & Total & 4 & 20 \\
\hline \multirow{6}{*}{$\begin{array}{l}\text { Q6. I know how to incorporate hearing/vision } \\
\text { support needs in ongoing management } \\
\text { plans. }\end{array}$} & Strongly agree & 0 & 0 \\
\hline & Agree & 0 & $4(20)$ \\
\hline & Neutral & $1(25)$ & $5(25)$ \\
\hline & Disagree & $2(50)$ & $10(50)$ \\
\hline & Strongly disagree & $1(25)$ & $1(5)$ \\
\hline & Total & 4 & 20 \\
\hline \multirow{7}{*}{$\begin{array}{l}\text { Q7. I am confident about helping residents } \\
\text { with dementia to use assistive hearing } \\
\text { devices, including hearing aids and TV } \\
\text { amplifiers. }\end{array}$} & Strongly agree & 0 & 0 \\
\hline & Agree & 0 & $6(30)$ \\
\hline & Neutral & $3(75)$ & $13(65)$ \\
\hline & Disagree & 0 & 0 \\
\hline & Strongly disagree & 0 & $1(5)$ \\
\hline & No response & $1(25)$ & - \\
\hline & Total & 4 & 20 \\
\hline \multirow{8}{*}{$\begin{array}{l}\text { Q7-1. If you are not confident in helping } \\
\text { residents with dementia us assistive } \\
\text { hearing devices, what specific difficulties } \\
\text { do you have? }\end{array}$} & Lack of training on use/maintenance & 0 & $3(15)$ \\
\hline & Lack of knowledge (hearing aid on/off) & $1(25)$ & 0 \\
\hline & Checking procedure to see if working & 0 & 0 \\
\hline & Changing batteries & 0 & 0 \\
\hline & Checking/cleaning for wax & 0 & $2(10)$ \\
\hline & Other & 0 & $2(10)$ \\
\hline & No response & $3(75)$ & $13(65)$ \\
\hline & Total & 4 & 20 \\
\hline
\end{tabular}

Values are presented as $\mathrm{n}(\%) . \mathrm{TV}$ : television 
Table 4. Sample results from the attitude section for nurse and allied health care professionals $(n=4)$ and caregivers $(n=20)$

\begin{tabular}{|c|c|c|c|}
\hline Item number & Response & $\begin{array}{l}\text { Nurse and allied health } \\
\text { care professional }\end{array}$ & Caregiver \\
\hline \multirow{6}{*}{$\begin{array}{l}\text { Q1. A brief hearing/vision screen would be acceptable for } \\
\text { residents with dementia. }\end{array}$} & Strongly agree & $1(25)$ & 0 \\
\hline & Agree & $1(25)$ & $8(40)$ \\
\hline & Neutral & $2(50)$ & $9(45)$ \\
\hline & Disagree & 0 & $3(15)$ \\
\hline & Strongly disagree & 0 & 0 \\
\hline & Total & 4 & 20 \\
\hline \multirow{6}{*}{$\begin{array}{l}\text { Q2. I would find clinical guidelines for assessing and } \\
\text { managing hearing/vision impairment during residential } \\
\text { aged care useful. }\end{array}$} & Strongly agree & 0 & 0 \\
\hline & Agree & 0 & $10(50)$ \\
\hline & Neutral & $2(50)$ & $8(40)$ \\
\hline & Disagree & $2(50)$ & $2(10)$ \\
\hline & Strongly disagree & 0 & 0 \\
\hline & Total & 4 & 20 \\
\hline \multirow{7}{*}{$\begin{array}{l}\text { Q3. Most residents with dementia who need a hearing aid } \\
\text { (or other assistive hearing device) can use one effectively. }\end{array}$} & Strongly agree & 0 & 0 \\
\hline & Agree & 0 & $9(45)$ \\
\hline & Neutral & $3(75)$ & $7(35)$ \\
\hline & Disagree & 0 & $4(20)$ \\
\hline & Strongly disagree & 0 & 0 \\
\hline & No response & $1(25)$ & - \\
\hline & Total & 4 & 20 \\
\hline \multirow{9}{*}{$\begin{array}{l}\text { Q3-1. If most residents with dementia who need a hearing } \\
\text { aid do not use one effectively, what are the reasons for } \\
\text { that ineffective use? }\end{array}$} & Does not fit properly & 0 & $2(10)$ \\
\hline & Hard to use & 0 & 0 \\
\hline & Not tolerated & $1(25)$ & $3(15)$ \\
\hline & Too expensive & 0 & $1(5)$ \\
\hline & Lost or broken & 0 & $4(20)$ \\
\hline & Not effective & 0 & 0 \\
\hline & Other & 0 & 0 \\
\hline & No response & $3(75)$ & $10(50)$ \\
\hline & Total & 4 & 20 \\
\hline
\end{tabular}

Values are presented as $\mathrm{n}(\%)$.

Thus, the practice, e.g., test and interpretation of those results and checking an assistive device, was not possible in the current situation. However, our respondents did some positive attitudes toward screen for hearing loss and helping elderly with dementia wear their hearing aids if specific clinical guidelines were provided.

Although we consider that direct support of hearing and vision impairments, by fitting hearing aids and eye glasses, is unlikely to succeed in the context of more serious cognitive deficits, such as dementia, and many do think about the complexity of concurrent deficits as well as the low rate of access to vision and hearing services in many elderly people, the related studies have proven that untreated hearing loss negatively affects dementia. Although the current data was only a small sample and limited to a specific regional area, there is a lack of systematic care for dementia patients with hearing loss in Korea, which warrants a follow-up study having a large size of samples collected from equally regional distributions. In conclusion, a more comprehensive approach for improving outcomes in people with both dementia and sensory impairments is needed in the future and further study for developing needed clinical guidelines for all levels of the health care professionals would be a good option and a positive change for better care for the elderly, especially those with dementia.

\section{Acknowledgments}

The authors sincerely thank Prof. Piers Dawes, University of Manchester to permit the translation of the K-KAP questionnaire. We also thank Prof. Jin-A Chun, Hallym University to assist collecting our pilot data from the facilities. This work was supported by the Ministry of Education of the Republic of Korea and the National Research Foundation of Korea (NRF-2018S1A3A2074932).

\section{Conflicts of interest}

The authors have no financial conflicts of interest.

\section{Author Contributions}

Conceptualization: Sunghwa You and Woojae Han. Formal analysis: Sunghwa You. Funding acquisition: Woojae Han. Project admin- 
You S, et al.

Table 5. Sample results for practice section from nurse and allied health care professionals $(n=4)$ and caregivers $(n=20)$

\begin{tabular}{|c|c|c|c|}
\hline Item number & Response & $\begin{array}{l}\text { Nurse and allied } \\
\text { health care professional }\end{array}$ & Caregiver \\
\hline \multirow{3}{*}{$\begin{array}{l}\text { Q1. Do you carry out the testing or checking } \\
\text { of hearing aids? }\end{array}$} & Yes & 0 & $4(20)$ \\
\hline & No & $4(100)$ & $16(80)$ \\
\hline & Total & 4 & 20 \\
\hline \multirow[t]{5}{*}{ Q1-1. If Yes } & Patient report & 0 & $1(5)$ \\
\hline & Caregiver report & 0 & $1(5)$ \\
\hline & Checking whether device working & 0 & $6(30)$ \\
\hline & No response & $4(100)$ & $12(60)$ \\
\hline & Total & 4 & 20 \\
\hline \multirow{3}{*}{$\begin{array}{l}\text { Q2. Do you carry out testing or checking } \\
\text { of spectacles? }\end{array}$} & Yes & 0 & $4(20)$ \\
\hline & No & $4(100)$ & $16(80)$ \\
\hline & Total & 4 & 20 \\
\hline \multirow[t]{6}{*}{ Q2-1. If Yes } & Patient report & 0 & $2(10)$ \\
\hline & Caregiver report & 0 & 0 \\
\hline & Check whether glass is clean & 0 & $2(10)$ \\
\hline & Check whether the glasses are suitable & 0 & $2(10)$ \\
\hline & No response & $4(100)$ & $14(70)$ \\
\hline & Total & 4 & 20 \\
\hline Q3. Do you have specifically designated staff & Yes & $2(50)$ & $6(30)$ \\
\hline held responsible for care of hearing (e.g., & No & $2(50)$ & $14(70)$ \\
\hline putting a hearing aid on, changing batteries)? & Total & 4 & 20 \\
\hline Q5. I have adequate training and support to & Yes & $1(25)$ & $7(35)$ \\
\hline use sensory support equipment (hearing aids, & No & $3(75)$ & $13(65)$ \\
\hline amplifiers, lighting). & Total & 4 & 20 \\
\hline
\end{tabular}

Values are presented as $\mathrm{n}(\%)$.

istration: Woojae Han. Visualization: Sunghwa You. Writing —original draft: Sunghwa You. Writing—review \& editing: Woojae Han.

\section{ORCID iDs}

Sunghwa You

Woojae Han

https://orcid.org/0000-0003-2458-4509

https://orcid.org/0000-0003-1623-9676

\section{REFERENCES}

1) Korean Statistical Information Service (KOSIS). Population projections and summary indicators (Korea): 2015-2065 [Internet]. Daejeon: KOSIS; 2018 [cited 2018 Dec 8]. Available from: URL: http:// kosis.kr/statHtml/statHtml.do?orgId=101\&tblId=DT_1BPA002\&co nn_path=I2\&language $=e n$.

2) World Health Organization (WHO). Dementia cases set to triple by 2050 but still largely ignored [Internet]. Geneva: WHO; 2012 [cited 2019 Jan 9]. Available from: URL: https://www.who.int/mediacentre/ news/releases/2012/dementia_20120411/en/.

3) Gurgel RK, Ward PD, Schwartz S, Norton MC, Foster NL, Tschanz JT. Relationship of hearing loss and dementia: a prospective, population-based study. Otol Neurotol 2014;35:775-81.

4) Lin FR. Hearing loss and cognition among older adults in the United States. J Gerontol A Biol Sci Med Sci 2011;66:1131-6.

5) Lin FR, Metter EJ, O'Brien RJ, Resnick SM, Zonderman AB, Ferrucci L. Hearing loss and incident dementia. Arch Neurol 2011;68: 214-20.

6) Lin MY, Gutierrez PR, Stone KL, Yaffe K, Ensrud KE, Fink HA, et al. Vision impairment and combined vision and hearing impairment predict cognitive and functional decline in older women. J Am Geri- atr Soc 2004:52:1996-2002.

7) Ong SY, Cheung CY, Li X, Lamoureux EL, Ikram MK, Ding J, et al. Visual impairment, age-related eye diseases, and cognitive function: the Singapore Malay Eye study. Arch Ophthalmol 2012;130:895-900.

8) Reyes-Ortiz CA, Kuo YF, DiNuzzo AR, Ray LA, Raji MA, Markides KS. Near vision impairment predicts cognitive decline: data from the Hispanic Established Populations for Epidemiologic Studies of the Elderly. J Am Geriatr Soc 2005;53:681-6.

9) Thomson RS, Auduong P, Miller AT, Gurgel RK. Hearing loss as a risk factor for dementia: a systematic review. Laryngoscope Investig Otolaryngol 2017;2:69-79.

10) Uhlmann RF, Larson EB, Koepsell TD, Rees TS, Duckert LG. Visual impairment and cognitive dysfunction in Alzheimer's disease. J Gen Intern Med 1991;6:126-32.

11) Horowitz A. The prevalence and consequences of vision impairment in later life. Top Geriatr Rehabil 2004;20:185-95.

12) Strawbridge WJ, Wallhagen MI, Shema SJ, Kaplan GA. Negative consequences of hearing impairment in old age: a longitudinal analysis. Gerontologist 2000;40:320-6.

13) Schopper D, Doussantousse S, Orav J. Sexual behaviors relevant to HIV transmission in a rural African population. How much can a KAP survey tell us? Soc Sci Med 1993;37:401-12.

14) Chien-Yun D, Wan-Fei C, Yu-Hsi Y, Chia-Hung Y. A study on modification of knowledge, attitude and practice on vocational high school electronics courses integrated with nanotechnology concept. Int J of Thermal \& Environmental Engineering 2012;4:73-9.

15) Pye A, Charalambous AP, Lerio I, Thodi C, Dawes P. Screening tools for the identification of dementia for adults with age-related acquired hearing or vision impairment: a scoping review. Int Psychogeriatr 2017;29:1771-84. 